\title{
Arsenic Concentration in Groundwater of Meherpur District, Southwestern Bangladesh: Sources of Arsenic, Quality Evaluation for Irrigation and Health
}

\section{Md. Shazzadur Rahman}

University of Rajshahi

A.H.M. Selim Reza ( $\square$ sreza69@yahoo.com )

University of Rajshahi

Aminul Ahsan

Bangladesh Council of Scientific and Industrial Research

Md. Abu Bakar Siddique

Bangladesh Council of Scientific and Industrial Research

\section{Research Article}

Keywords: Arsenic, Groundwater, Irrigation water Indices, Multivariate statistical approaches, Human health risks

Posted Date: January 24th, 2022

DOI: https://doi.org/10.21203/rs.3.rs-1263258/v1

License: (c) (i) This work is licensed under a Creative Commons Attribution 4.0 International License. Read Full License 


\section{Arsenic concentration in Groundwater of Meherpur district, southwestern}

Bangladesh: Sources of Arsenic, Quality evaluation for irrigation and Health

Md. Shazzadur Rahman ${ }^{1}$, A.H.M. Selim Reza ${ }^{1}$, Aminul Ahsan², Md. Abu Bakar Siddique $^{2}$

${ }^{1}$ Department of Geology and Mining, University of Rajshahi, Rajshahi-6205, Bangladesh

${ }^{2}$ Analytical Research Division, BCSIR Laboratories, Dhaka-1205, Bangladesh

${ }^{*}$ Corresponding Author.

E-mail Address: sreza69@yahoo.com

\section{Abstract}

In Bangladesh, groundwater arsenic poisoning has become one of the biggest concern because of its use for irrigation and domestic purposes. High arsenic concentration in groundwater, soil and crops around the study area are of the greatest environmental concern and a matter of interest about human health. Groundwater, soil and crops samples collected from Bholadanga, Meherpur district, southwestern Bangladesh to measure arsenic concentration and human health risk assessment. $\mathrm{pH}$ value of collected groundwater samples range from 7.17 to 8.09 which exhibit lightly acidic nature.The average abundance of major cations is $\mathrm{Ca}^{2+}>\mathrm{Mg}^{2+}>\mathrm{Na}^{+}>\mathrm{K}^{+}$and among major anions is $\mathrm{HCO}_{3}^{-}>\mathrm{Cl}^{-}>\mathrm{NO}_{3}^{-}>$ $\mathrm{SO}_{4}{ }^{2-}$ whereas $\mathrm{Ca}^{2+}$ is the dominant cations and $\mathrm{HCO}_{3}{ }^{-}$dominant anions. Arsenic as well as other cations and metal like $\mathrm{Fe}, \mathrm{Mn}, \mathrm{Cr}, \mathrm{Cd}, \mathrm{Pb}, \mathrm{Co}, \mathrm{Ni}$ and so on were determined for all sorts of samples in order to assess their concentration and possible health hazard with a different statistical approaches. Principal component and cluster analyses suggested significance metal concentration in samples. At the shallow aquifer $(50-60 \mathrm{~m}$ of depth) concentration of arsenic in groundwater varies from 13.1 to $292 \mu \mathrm{g} / \mathrm{L}$. In groundwater approximately all the trace metals concentration are within the WHO and DOE limit except Mn, As and Fe. So groundwater of the study area are contaminated with arsenic and which is not 
compatible for drinking as well as irrigation purposes. Piper Tri-linear, Durov and Schoeller Semi Logarithmic diagram have been prepared based on chemical analysis of major cations and anion data and these three diagrams express that groundwater of the study area is $\mathrm{Ca}-\mathrm{HCO}_{3}$ type, where $\mathrm{Ca}$ and $\mathrm{HCO}_{3}$ is the principal cations and anion, respectively. Genetically groundwater collected from the study area is 'normal chloride water' based on chloride, 'normal sulfate water' based on sulfate and 'elevated nitrate present' based on nitrate concentration. Based on SAR, TH, SSP, KR, MH, TH, Na\%, PI and PS values, it can be concluded that the groundwater collected from the investigated area is compatible for agricultural activities. Cancer risk, daily ingestion of metal, potential hazard quotient and carcinogenic risk are used to calculate possible health hazard in the study area. Average cancer risk value is 0.0057 from drinking water suggest that people of that area are at high cancer risk according to USEPA.

\section{Keywords}

Arsenic, Groundwater, Irrigation water Indices, Multivariate statistical approaches, Human health risks

\section{Introduction}

Arsenic is known as one of the most common world environmental toxicants. Groundwater arsenic poses a significant health anxiety in Asia. Today groundwater resources contaminated with arsenic have been invented in many place of Bangladesh, India, Pakistan, China, Myanmar, Mongolia, Cambodia, Nepal, Thailand, Viet Nam, Chile, Argentina, and USA (Reza et al., 2010; Ng et al., 2003; Smedley and Kinniburgh, 2002; Mandal and Suzuki, 2002). Arsenic contamination is considered a silent killer in all over the globe. The arsenic fatality of Bangladesh has been determined as the greatest inflammation in the history. Currently, 59 district out of 64 across the country are stricken by arsenic 
contamination. According as, more than 80 million people are present at risk and 10 thousand people have already displayed the arsenicosis symptoms (Chowdhury, 2001). People exposed to arsenic mostly by drinking water contaminated by arsenic poisoning (Rabbani et al., 2002). The high levels of groundwater arsenic in the GMB (Ganges-Meghna-Brahmaputra) basin are of natural in origin. The two major principle on the fundamental processesare oxidation of arsenic bearing pyrite minerals and the reductive dissolution of iron oxyhydroxides $(\mathrm{FeOOH})$ in together with discharge of As in our environment (Ahmed et al., 2004; McArthur et al., 2004; Zheng et al., 2004; Smedley and Kinniburgh, 2002). More proof in favor of dissolution of $\mathrm{FeOOH}$ has been acquired in the last couples of years (Ravenscroft et al., 2001). Though oxidation of pyrite minerals due to a lowering groundwater table supposed to be cropped but there still is arguments whether or not groundwater expulsion for irrigation purposes influences arsenic behavior in the shallow aquifer. Organic matter entrance into the shallow aquifer causes dissolution of iron oxyhydroxides $(\mathrm{FeOOH})$ (Harvey et al., 2002). Arsenic is entirely spread as trace elements in aquifer materials and soils in Meherpur district, southwestern Bangladesh.

Long-standing As contamination can cause dangerous health effects together with melanosis (dark and white spots), hyperkeratosis (obdurate skin), cancers, gangrene, lung enlargement, hypertension, Blackfoot disease, diabetes mellitus and ischemic heart disease (Rahman, 2002; Srivastava et al., 2001; Guha-Mazumder et al., 2000; Morales et al., 2000; Lin et al., 1998; Chen et al., 1995).The present research is guided to determine the groundwater quality for ascertaining its excellence for different uses. The main aim of this thesis work is to determine the groundwater quality for drinking, domestic and irrigation purposes and to assess health risk associated with arsenic contamination. 


\section{Materials and Methods}

\section{Site description}

The study area is located in the Bholadanga village under Sholataka union of Gangni upazila, Meherpur, southwestern Bangladesh. It covers the portion of the southwestern part of Bangladesh and is located in the graphical co-ordinates between $23^{\circ} 51^{\prime} 00^{\prime \prime}$ to $23^{\circ} 51^{\prime} 15^{\prime \prime}$ north latitudes and in between $88^{\circ} 51^{\prime \prime} 35^{\prime \prime}$ to $88^{\circ} 51^{\prime} 50^{\prime \prime}$ east longitudes. It is bounded by Doulatpur upazila on the north, Mirpur upazila in the east, Alomdanga upazila in the south, and Meherpur sadar upazila on the west. This area covers $1.5 \mathrm{sq}$. $\mathrm{km}$. which covers Bholadanga village area (fig. $1)$.

\section{Sampling}

Groundwater samples were taken from hand and electric pumps at a depth ranges from $50 \mathrm{~m}$ to $70 \mathrm{~m}$ located in the Bholadanga village under Gangni upazila in Meherpur, southwestern Bangladesh in April, 2019. Before collecting groundwater samples all pumps and wells were being flushed for five minutes to geta new groundwater earlier to collect samples and stored in a new plastic bottle of $250 \mathrm{ml}$ capacity. Groundwater samples $(250 \mathrm{ml}$ of each) were collected in triplicate in three separate plastic bottles consist of airtight caps. Ten samples were acidified with 2-3 drops of concentrated nitric acid $\left(\mathrm{HNO}_{3}\right)$ during collection for the measurement of trace elements to prevent any unexpected reaction causing precipitation and all the samples were marked and samples were concealed in insulated cooler bearing ice, transported to the laboratory and stored at $4^{\circ} \mathrm{C}$. All essential water sampling guidelines were followed during collection of samples. The physical parameters such as $\mathrm{pH}, \mathrm{EC}$, ORP, temperature and TDS were measured in the field. Major cations, anions and trace elements concentrations 
were measured at Institute of National Analytical Research and Service (INARS), BCSIR, Dhaka, Bangladesh.

\section{Analytical Methods}

The $\mathrm{pH}$ and Electrical Conductance (EC) of groundwater samples were measured in the field by using a portable $\mathrm{pH}$ (Model: pH211, Hanna instrument, Portugal) and EC (Model: Lutron CD-4301) meter. In laboratory TDS measured by portable $\mathrm{HACH}$ machine. Oxidation-reduction potential which were carried out using portable ORP meters (Toko Chemicals Laboratories Co. Ltd., Tokyo, Japan). Dominant cations, anion and trace elements concentrations were measured at Institute of National Analytical Research and Service (INARS), BCSIR, Dhaka, Bangladesh. To measure the metal concentrations we used all traceable standard solution according to National Institute of Standards and Technology (NIST). Flame photometer (AnA-135, O.S.KOGAWA SEIKI Co. LTD, JAPAN), Shimadzu Ion Chromatograph, HIC-10-A and Varian spectra AA 240 FS were used to get metal concentrations in water.

\section{Quality Control}

The analyses were carefully assured in all respects of the thesis work period beginning since samples collection to analyses in the laboratory. For sample preparation, analytical-grade reagents like $\mathrm{HNO}_{3}, \mathrm{HClO}_{4}, \mathrm{H}_{2} \mathrm{O}_{2}$ and deionized water (resistance $18.2 \mathrm{M} \Omega \mathrm{cm}$ at $25{ }^{\circ} \mathrm{C}$ and electrical conductivity $0.2 \mu \mathrm{S} \mathrm{cm}^{-1}$ ) were used. All experimental glass wares like pipette, volumetric flask were well calibrated and cleaned with $\mathrm{HNO}_{3}$ overnight and then rinsed with deionized water to reduce any sorts of anomaly during analyses. For samples weighing a calibrated digital electrical balance (GR-200, A\&D CompanyLimited, Tokyo, Japan) was used. The instruments were calibrated with the certified reference materials (CRM) (Fluka Analytical, Sigma-Aldrich, Germany) of $1000 \pm 4 \mathrm{mg} / \mathrm{L}$ stock solution as 
traceable to the National Institute of Standards and Technology (NIST), USA. Accuracy and precision were checked with replicate analysis against NIST traceable CRM.

\section{Data Analysis}

\section{Statistical Analysis}

For analytical calculation Microsoft Excel 2013, Aqua Chem and SPSS statistic software (version 20, IBM Corporation, Armonk, New York, USA) were used.

\section{Irrigation water indices}

\section{Sodium Adsorption Ratio (SAR)}

Sodium adsorption ratio (SAR) is one of the most important factor for realizing suitability of water for agricultural activities. Higher the SAR value less the suitability. Irrigation with high SAR value cause soil degradation.

$\mathrm{SAR}=\frac{\mathrm{Na}^{+}}{\sqrt{\frac{\left(\mathrm{Ca}^{2+}+\mathrm{Mg}^{2+}\right)}{2}}}$

According to SAR value, irrigation water quality can be grouped into four categorieswhich as follows; SAR $<10$ (suitable or ideal), 10-18 (good/ acceptable), 18-26 (distrustful) and SAR > 26 (unsuitable).

\section{Percent sodium (\% Na) or sodium hazard}

High concentration of $\mathrm{Na}^{+}$in water affects the soil permeability and causes infiltration problems and results in staving of soil aggregation. In dry condition soil becomes hard and decreases infiltration rates.

$\mathrm{Na} \%=\frac{\mathrm{Na}^{+}}{\mathrm{Na}^{+}+\mathrm{K}^{+}+\mathrm{Ca}^{2+}+\mathrm{Mg}^{2+}} \times 100$

The alignment of water is based on $\% \mathrm{Na}$ as $<20 \%$ (ideal/ excellent), $20-40 \%$ (Good), $\quad 40-60 \% \quad$ (permissible), $\quad 60-80 \% \quad$ (questionable) and $>80 \%$ (unsuitable/polluted) (Khodapanah et al. 2009). 


\section{Soluble sodium percentage (SSP)}

Low soluble sodium percentage is good for irrigation or agricultural production. Four classes of SSP (Todd 1980 and Wilcox 1955) value were developed.

$\mathrm{SSP}=\frac{\mathrm{Na}^{+}+\mathrm{K}^{+}}{\mathrm{Na}^{+}+\mathrm{K}^{+}+\mathrm{Ca}^{2+}+\mathrm{Mg}^{2+}} \times 100$

Groundwater classification based on SSP graded as <20 (Excellent), 20-40 (Good), 40-80 (Doubtful) and >80 (Unsuitable).

\section{Magnesium adsorption ratio (MAR)}

Magnesium adsorption ratio is believed that one of the most important essential parameter in classifying the irrigation water quality. High amounts of $\mathrm{Mg}$ in irrigation water affects soil physical properties. Negative effects on soils observe when $\mathrm{Ca}: \mathrm{Mg}$ ratio decline below 50 .

$\mathrm{MH}=\frac{\mathrm{Mg}^{2+}}{\mathrm{Ca}^{2+}+\mathrm{Mg}^{2+}} \times 100$

Magnesium hazard $>50$ is not suitable for agricultural activities (Khodapanah et al. 2009).

\section{Kelley's Ratio (KR)}

Kelly (1940) and Paliwal (1967) developed another factor to evaluate quality and arrangement of groundwater for agricultural activitiesfounded on the amounts of $\mathrm{Na}^{+}$compared with $\mathrm{Ca}^{2+}$ and $\mathrm{Mg}^{2+}$.

$\mathrm{KR}=\frac{\mathrm{Na}^{+}}{\mathrm{Ca}^{2+}+\mathrm{Mg}^{2+}}$

$\mathrm{KR} / \mathrm{KI}>1$ suggests a high amount of $\mathrm{Na}^{+}$in waters. When groundwater with a $\mathrm{KI} \leq$ 1 has been suitable for agricultural practices, while groundwater contain $\mathrm{KI} \geq 1$ is not permissible for irrigation due to alkali hazards (Ramesh and Elango 2012; Karanth 1987). 


\section{Total Hardness (TH)}

Total hardness is measured by the $\mathrm{Ca}^{2+}$ and $\mathrm{Mg}^{2+}$ content of water. Though $\mathrm{Ca}^{2+}$ and $\mathrm{Mg}^{2+}$ are essential plant nutrients, medium levels of hardness of 100 to 150 $\mathrm{mg} / \mathrm{L}$ are recommended for plant growth.

$\mathrm{TH}=2.5 \times \mathrm{Ca}^{2+}+4.1 \times \mathrm{Mg}^{2+}$

Total hardness is normally grouped as, 0-60 mg/l (soft/ very good), 60-120 mg/l (moderately hard/ good), 120-180 mg/l (hard) and > $180 \mathrm{mg} / \mathrm{l}$ (very hard) (EPA 1986).

\section{Permeability index (PI)}

Soil permeability is invaded by long-term irrigation with $\mathrm{Na}^{+}, \mathrm{Ca}^{2+}, \mathrm{Mg}^{2+}$ and $\mathrm{HCO}_{3}{ }^{-}$contents of the soil. The PI values suggests the propriety of groundwater for irrigation. The values are expressed in meq/l and developed by Doneen (1964).

$\mathrm{SSP}=\frac{\mathrm{Na}^{+}+\sqrt{\mathrm{HCO}_{3}}}{\mathrm{Na}^{+}+\mathrm{Ca}^{2+}+\mathrm{Mg}^{2+}} \times 100$

PI values classified as class-1 (PI > 75, Suitable), class-2 (PI= 25-75, Good) and class-3 (PI < 25, Unsuitable). Groundwater under class 1 and class 2 is recommended for agricultural activities.

\section{Potential salinity (PS)}

Potential salinity is another irrigation water quality parameter-based index (Doneen 1964) for classified of water for agricultural purposes. Potential salinity is less than $3 \mathrm{meq} / \mathrm{l}$ is a sign of the excellence of water for irrigation.

$\mathrm{PS}=\mathrm{Cl}^{-}+0.5 \times \mathrm{SO}_{4}{ }^{2-}$

\section{Human Health Risk Assessment}




\section{Average Daily Dose (ADD)}

To assess health risk, average daily dose (ADD) of arsenic because of the ingestion of arsenic contaminated drinking groundwater was estimated by the Equation (USEPA, 1998):

$\mathrm{ADD}=\frac{\mathrm{C} \times \mathrm{IR} \times \mathrm{ED} \times \mathrm{EF}}{\mathrm{BW} \times \mathrm{AT}}$

Where:

$\mathrm{C}=$ Water arsenic concentration $(\mathrm{mg} / \mathrm{L})$

IR = Ingestion rate of water (L/Day) (assumed 3.5 liter/day a person drink)

$\mathrm{ED}=$ Exposure duration or life expectancy (assumed 72 years for Bangladesh)

$\mathrm{EF}=$ Exposure frequency (365 days per year)

$\mathrm{BW}=$ Average body weight (avg. $65 \mathrm{~kg}$ in study area)

AT $=$ Average life time (26280 days)

\section{Hazard Quotient (HQ)}

Long-standing carcinogenic hazard levels were also measure for groundwater arsenic poisoning of the research area. The hazard quotient (HQ) was calculated by following formula, (USEPA, 1998)

$$
\mathrm{HQ}=\frac{\mathrm{ADD}}{\mathrm{RfD}}
$$

Where

$\mathrm{ADD}=$ Average Daily Dose

$\mathrm{RfD}=$ Referred oral reference dose $(0.0003 \mathrm{mg} / \mathrm{kg} / \mathrm{day})$ for arsenic established by US-EPA (USEPA, 2005).

\section{Cancer Risk (CR)}


Cancer risk (CR) was calculated by using the formula:

$$
\mathrm{CR}=\frac{\mathrm{ADD}}{\mathrm{CSF}}
$$

Where, CSF is the cancer slope factors $(1.5 \mathrm{mg} / \mathrm{kg} /$ day $)$ for arsenic in accordance with US-EPA (USEPA, 2005).

\section{Results and Discussion}

\section{Field Measurements}

The $\mathrm{pH}$ values of collected groundwater samples range from 7.17 to 8.09 (avg. 7.45) which is within permissible limit (6.5 to 8.5) suggested by WHO (1997) and $\mathrm{pH}$ value of aquifer indicate slightly alkaline state(Table 1$)$. The temperature of groundwater was identical and range from $24.3^{\circ} \mathrm{C}$ to $25.1^{\circ} \mathrm{C}$ with an average of $24.6^{\circ} \mathrm{C}$ (Table 1). The EC value of investigated groundwater samples range from 571 to $1056 \mu \mathrm{S} / \mathrm{cm}$ (avg. $754 \mu \mathrm{S} / \mathrm{cm}$ ) which indicate fresh or non-saline ( <1000 $754 \mu \mathrm{S} / \mathrm{cm})$ in nature shown in Table 1 .

\section{Hydrochemistry}

\section{Major cations and anions}

The average abundance of major cations and anions is $\mathrm{Ca}^{2+}>\mathrm{Mg}^{2+}>\mathrm{Na}^{+}>\mathrm{K}^{+}$and $\mathrm{HCO}_{3}{ }^{-}>\mathrm{Cl}^{-}>\mathrm{NO}_{3}{ }^{-}>\mathrm{SO}_{4}{ }^{2-}$ where $\mathrm{Ca}^{2+}$ and $\mathrm{HCO}_{3}{ }^{-}$dominant cation and anion. Concentration of major cations like $\mathrm{Na}, \mathrm{K}, \mathrm{Ca}, \mathrm{Mg}$ of groundwater samples range from 20.5 to $48.9 \mathrm{mg} / \mathrm{L}$ (avg. $31.8 \mathrm{mg} / \mathrm{L}$ ); 2.65 to $33.3 \mathrm{mg} / \mathrm{L}$ (avg. $8.9 \mathrm{mg} / \mathrm{L}$ ); 41.5 to $85.4 \mathrm{mg} / \mathrm{L}$ (avg. $68.8 \mathrm{mg} / \mathrm{L}$ ) and 22.3 to $39.4 \mathrm{mg} / \mathrm{L}$ (avg. $34.2 \mathrm{mg} / \mathrm{L}$ ), respectively (Table 1). Major anions concentration like $\mathrm{HCO}_{3}{ }^{-}, \mathrm{Cl}^{-}, \mathrm{NO}_{3}{ }^{-}, \mathrm{SO}_{4}{ }^{-2}$ in groundwater range from 200 to $552 \mathrm{mg} / \mathrm{L}$ (avg. $388.71 \mathrm{mg} / \mathrm{L}$ ); 1.3 to $62.9 \mathrm{mg} / \mathrm{L}$ (avg. $31.4 \mathrm{mg} / \mathrm{L}$ ); 2.9 to $106.5 \mathrm{mg} / \mathrm{L}$ (avg. $14.6 \mathrm{mg} / \mathrm{L}$ ); 0.24 to $33.6 \mathrm{mg} / \mathrm{L}$ (avg. $8.8 \mathrm{mg} / \mathrm{L}$ ), respectively (Table 1 ). 


\section{Trace Metals Analyses}

Trace metals analyses of groundwater samples shown in Table 2. Among trace metals As, Fe and Mn concentrations in groundwater range from 13.1 to 292( $\mu \mathrm{g} / \mathrm{L})$ (avg. $156.9 \mu \mathrm{g} / \mathrm{L}) ; 0.3$ to $4.1 \mathrm{mg} / \mathrm{L}$ (avg. $2.32 \mathrm{mg} / \mathrm{L}$ ) and 0.02 to $1.4 \mathrm{mg} / \mathrm{L}$ (avg. $0.72 \mathrm{mg} / \mathrm{L})$, respectively.

\section{Graphical Presentation of Analytical Cations and Anion data of Groundwater}

Piper's Tri-linear and Durov diagram is a useful tool for arranging hydro-chemical analyses data for identifying the sources of the dissolved constituents in groundwater (Piper, 1953). From Piper's Tri-linear (fig. 2a) and Durov diagram (fig. 2b), collected groundwater samples are $\mathrm{Ca}-\mathrm{HCO}_{3}$ type in the Bholadanga village under Sholataka union of Gangni upazila, Meherpur, southwestern Bangladesh.

From the Schoeller diagram (fig. 2c), most of the collected samples show $\mathrm{Ca}$ $\mathrm{HCO}_{3}$ type of water, where $\mathrm{Ca}$ is the dominant cations and $\mathrm{HCO}_{3}$ is the dominant anion.

\section{Classification of Groundwater}

\section{Genetic Classifications}

Schoeller (1955),Madison and Brunett, (1994) classify water from various points of view like $\mathrm{Cl}^{-}, \mathrm{SO}_{4}{ }^{2-}$, and $\mathrm{NO}_{3}{ }^{-}$concentrations etc shown in Table 1. These are stated as below:

Concentrations of $\mathrm{Cl}^{-}$in groundwater range from 0.04 to $1.77 \mathrm{meq} / \mathrm{L}$ (avg. 0.88 meq/L), which suggests the groundwater is normal chloride water. In the research area the concentrations of $\mathrm{SO}_{4}{ }^{2-}$ in groundwater range from 0.005 to $0.7 \mathrm{meq} / \mathrm{L}$ (avg. $0.18 \mathrm{meq} / \mathrm{L}$ ), which reveal that the groundwater is normal sulfate water. In the study area concentrations of $\mathrm{NO}_{3}{ }^{-}$in groundwater range from $2.9 \mathrm{mg} / \mathrm{l}$ to 106.5 
$\mathrm{mg} / \mathrm{l}$ with an average value of $14.6 \mathrm{mg} / \mathrm{l}$ which indicates that concentration of nitrate is elevated related to the background value of $3 \mathrm{mg} / \mathrm{l}$.

\section{Assessment of Groundwater quality for drinking and Irrigation purposes}

To determine the quality for drinking water and public health, the physical and chemical propertiesof the groundwater were likened with the standard pattern recommended by the World Health Organization (WHO 1997) and Environmental Quality Standard for Bangladesh in following Table 3. From this correlation Table 3 , it can be summarized that $\mathrm{pH}$, TDS, $\mathrm{Na}^{+}, \mathrm{K}^{+}, \mathrm{Ca}^{2+}, \mathrm{Mg}^{2+}, \mathrm{Cl}^{-}, \mathrm{NO}_{3}{ }^{2-}, \mathrm{SO}_{4}{ }^{2-}$ (cations and anions) are within the standard limit which is permisible for domestic and drinking purposes and $\mathrm{As}, \mathrm{Fe}, \mathrm{Mn}$ (trace metals) values exceed the DOE and WHO standard are not suitable for human consumption.

To determine irrigation water quality several indices were calculated (Table 4), which are as follows;

Sodium Adsorption Ratio (SAR): Sodium adsorption ratio is the measure the degree to which irrigation water tends to enter the cation exchange reaction in soil stated by US salinity laboratory. The SAR value of the research area ranges from 0.59 to 1.13 with an average of 0.87 which are ideal or excellent $(\mathrm{SAR}<10)$ in quality for irrigation purposes.

Percent sodium (\% $\mathbf{N a}$ ): High level of $\mathrm{Na}^{+}$in irrigation water is not suitable for cultivation because $\mathrm{Na}^{+}$causes chemical reaction with soil to decrease water flowing capacity through soil (Ayers and Westcot 1985). The Na percentage groundwater samples collected from the investigated areas ranges from 15.88 to 22.90 with an average of 19.65 which indicate good to excellent $(\% \mathrm{Na}<40)$ in quality for irrigation.

Soluble sodium percentage (SSP): Soluble sodium percent (SSP) is a significant factor for the classification of irrigation water. Low SSP value (SSP < 20\%) 
considered best quality for irrigation purposes. The SSP values ranges from 17.23 to 27.8 (avg. 22.68) indicate good (20-40\%) quality for irrigation.

Magnesium adsorption ratio (MAR): High amounts of $\mathrm{Mg}^{2+}$ in groundwater causes high $\mathrm{pH}$ condition in soil, damage soil quality and finally decreases crop yield. Magnesium hazard ( $\mathrm{MH})$ less than 50 is considered best for irrigation. In the study areas $\mathrm{MH}$ values ranges from 40.29 to 46.98 (avg. 44.77) which recommended for suitable irrigation purposes.

Kelley's ratio (KR): Kelly's ratio (KR) is an indicator to determine irrigation water propriety and it is free from the effect of $\mathrm{K}^{+}$parameter, which largely depends on calcium, magnesium and sodium ions. The KR value ranges from 0.19 to 0.30 (avg. 0.25 ) which indicate groundwater is suitable for cultivation.

Total Hardness (TH): Total hardness is an important parameter of water for the utility in various industrial, domestic or agricultural activities. The total hardness of water measure from the excess amount of $\mathrm{Ca}, \mathrm{Mg}$ and $\mathrm{Fe}$ presence in water. The TH value of the study areas ranges from 12.7 to 22.75 (avg. 18.83) which suggest soft groundwater condition and best for irrigation and other domestic purposes.

Permeability index (PI): The permeability of soil is influenced by the regular use of water enriched with $\mathrm{Na}^{+}, \mathrm{Ca}^{2+}, \mathrm{Mg}^{2+}$ and $\mathrm{HCO}_{3}{ }^{2-}$ ions, the soil is augmented by the utility of irrigation water (Chandu et al. 1995). The PI is a measure competent of water for cultivation. PI values of the research area ranges from 49.85 to 59.07 (avg. 54.64) which recommended suitable for irrigation purposes.

Potential salinity (PS): Potential salinity is less than $3 \mathrm{meq} / \mathrm{l}$ is suitable for safe irrigation. The PS values of the study areas ranges from 0.18 to 1.81 (avg. 0.98) which suggest that PS value is safe for irrigation. 


\section{Graphical Representation of Concentrations of As, Fe and Mn with WHO and Bangladesh Domestic Water Quality Standard}

In following figures 3, fig. 3(a) arsenic concentrations in all groundwater samples overstep the WHO Guideline for Drinking Water Quality (GDWQ) value (10 $\mu \mathrm{g} / \mathrm{L})$ and two samples out of 10 are within the Bangladesh domestic water quality standard value $(50 \mu \mathrm{g} / \mathrm{L})$. In fig. 3(b), iron concentrations in all groundwater samples exceed WHO (0.3 mg/L) and one sample is within DOE standard (0.3 to 1 $\mathrm{mg} / \mathrm{L}$ ). In fig. 3(c) Manganese concentrations show seven samples exceed the WHO value $(0.5 \mathrm{mg} / \mathrm{L})$ and nine samples exceed DOE values of $(0.1 \mathrm{mg} / \mathrm{L})$.

\section{Correlation Analyses among Different Chemical Elements of the Groundwater Samples}

In the following correlation (figure 4) it is noticed that arsenic is poorly correlated with $\mathrm{Fe}\left(\mathrm{R}^{2}=0.0794\right), \mathrm{Mn}\left(\mathrm{R}^{2}=0.0121\right)$ and $\mathrm{SO}_{4}\left(\mathrm{R}^{2}=0.0401\right)$ in fig. 4(a), 4(b) and $4(\mathrm{c})$, respectively. Sulphate is poorly correlated with $\mathrm{Fe}\left(\mathrm{R}^{2}=0.0067\right)$ and $\mathrm{Mn}$ $\left(\mathrm{R}^{2}=0.0093\right)$ in fig. $4(\mathrm{~d})$ and $4(\mathrm{e})$, respectively. Finally Iron shows moderately correlated with $\mathrm{Mn}\left(\mathrm{R}^{2}=0.7696\right)$ in fig. 4(f).

Poorly to moderate correlations among soluble As, Fe and Mn concentration (As vs. Fe, $\left.\mathrm{R}^{2}=0.0794\right)$; (As vs. $\mathrm{Mn}, \mathrm{R}^{2}=0.0121$ ) suggest that reductive dissolution of $\mathrm{MnOOH}$ and $\mathrm{FeOOH}$ where anaerobic bacteria represents a vital mechanism for arsenic discharge into the groundwater.

The weakly correlations among dissolved $\mathrm{As}, \mathrm{Fe}$ and $\mathrm{SO}_{4}$ concentration (As vs. $\left.\mathrm{SO}_{4}, \mathrm{R}^{2}=0.0401\right)$; (Fe vs. $\left.\mathrm{SO}_{4}, \mathrm{R}^{2}=0.0067\right)$ in groundwater suggest that oxidation of pyrite is not the principal process of arsenic release into groundwater.

\section{Sources of Metals Concentration in Groundwater}

Principal component analysis (PCA) was used for identification of contaminant source either of anthropogenic activities or geogenic in origin (Ahsan et al., 2019). 
The PCA analysis results of metals content in water samples are presented in table 5.

Four principal component were identified for water samples(fig. 5). PCA analysis of water samples explained the cumulative variance of $86.63 \%, 71.62 \%, 52.20 \%$ and $31.42 \%$, respectively. First principal component (PCA-1) for water sample showed the positive loadings of $\mathrm{Mg}, \mathrm{Ca}, \mathrm{Na}$ and $\mathrm{K}$ which are dissolved salt. $\mathrm{Ca}$ and $\mathrm{Mg}$ dissolved in water mainly derived from minerals like dolomite $\{\mathrm{Ca} \mathrm{Mg}$ $\left.\left.\left(\mathrm{CO}_{3}\right)_{2}\right)\right\}$ and limestone.Most groundwater contain less than $20 \mathrm{mg} / \mathrm{L}$ of sodium. Fertilizer used in agriculture leaches $\mathrm{Na}$ and $\mathrm{K}$ to groundwater may enrich salt content in water. Positive loading of Fe, $\mathrm{Mn}$ and $\mathrm{Zn}$ in PCA-2 showed that these are indicative of reducing environment. $\mathrm{Cd}$ and $\mathrm{Pb}$ are the dominant metals of PCA-3 indicate anthropogenic in origin due to using fertilizer like phosphate and it's going downward through leaching. Arsenic is the significant value of PCA-4 which is mainly geogenic in origin. Again, cluster analyses (CA) was accomplished with Ward's methods to classify the metals into various groups and the results exhibitwith a dendrogram (Fig. 6). Four main clusters were identified for water sample with the phenon line set to a rescaled distance of about 10 to show statistical similarity. Cluster 1 for water sample included $\mathrm{Mg}, \mathrm{Ca}, \mathrm{Na}$ and $\mathrm{K}$ which showed positive accumulation on PCA-1 similarly cluster 2, cluster 3 and cluster 4 include $\mathrm{Fe}, \mathrm{Mn}, \mathrm{Zn} ; \mathrm{Cd}, \mathrm{Pb}$; and $\mathrm{As}$ which showed the similar positive loading on PCA-2, PCA-3 and PCA-4, respectively.

\section{Human Health Hazard Assessment from Drinking Water}

The human health hazard assessment model developed by United States Environmental Protection Agency (USEPA, 1998) was utilized to calculate the noxious impacts of arsenic contamination in drinking water on people. The average daily dose (ADD), hazard quotient (HQ) and cancer risk (CR) from arsenic 
exposure are considered for this purposes shown in table 6. The health hazard measurement was performed by calculating the possibility of individuals being exposed to contamination of arsenic from drinking water.

\section{Results of ADD, HQ and CR from Drinking Water}

Here we considered the maximum, minimum and average concentration of arsenic for groundwater. Water arsenic concentration in the study area shows normal value of average daily dose in accordance with FAO and WHO acceptable daily dose of arsenic is $100 \mu \mathrm{g} / \mathrm{L}$. But HQ value greater than 1 indicate that people of the study area were at highly carcinogenic hazard. The enumerated cancer risk (CR) values were greater than that of the United States Environmental Protection Agency (USEPA) limit $\left(10^{-6}\right)$ which revealing that the people in vicinity of the area were at high carcinogenic hazard. So that, the regular monitoring of arsenic level in groundwater is necessary in order to measure if any potential health hazard from consumptions of arsenic rich water exist, thereby protecting every single person from drinking of arsenic contaminated water that might be poisonous to their health.

\section{Conclusion}

The $\mathrm{pH}$ value of the groundwater samples collected from Bholadanga, Meherpur, southwestern Bangladesh is 7.17 to 8.09 which suggests normal fresh to minor alkaline water. Electrical conductance of groundwater sample range from 571 to $1056 \mu \mathrm{S} / \mathrm{cm}$ which are excellent for irrigation purposes and classified as non-saline in taste. Average temperature ranges from 24.3 to $25.1^{\circ} \mathrm{C}$. TDS value ranges from 283 to $519 \mathrm{mg} / \mathrm{L}$ indicate palatability of water is good and which is safe for drinking purposes. The cations analysis $(\mathrm{Na}, \mathrm{K}, \mathrm{Ca}, \mathrm{Mg}$ ) of the groundwater sample collected from the study area revealed that values of those elements are normal in ranges and safe for drinking and as well as domestic purposes. Anions analysis $(\mathrm{Cl}$, $\mathrm{NO}_{3}$ and $\mathrm{SO}_{4}$ ) show that all the sample from within the permissible limit except 
one sample which exceeds World Health Organization (WHO) and Department of Environment (DoE) standard for Nitrate.Groundwater quality of the study area by comparison with WHO and DoE standards shows that the trace element Fe,As and Mn exceed the WHO and DoE standard. It strongly indicate that groundwater sample from Bholadanga village area is affected by arsenic contamination and which is not suitable not only for drinking purposes but also irrigation and other domestic uses.All of these three diagram Piper Tri-linear, Durov and Schoeller Semi Logarithmic express that groundwater of the study area is $\mathrm{Ca}-\mathrm{HCO}_{3}$ type, where $\mathrm{Ca}$ and $\mathrm{HCO}_{3}$ is the dominant cations and anion, respectively. Genetically groundwater collected from Bholadanga, Meherpur, Southwestern Bangladesh area is 'normal chloride water' based on chloride, 'normal sulfate water' based on sulfate and 'elevated nitrate present' based on nitrate concentration. Arsenic concentration in groundwater in shallow aquifer (50 to $60 \mathrm{~m}$ depth) range from 13.1 to $292 \mu \mathrm{g} / \mathrm{L}$ in Bholadanga, Meherpur, southwestern Bangladesh showed that groundwater of the research area is highly toxic to human health. Poorly to moderately correlations among dissolved As, Fe and Mn concentration (As vs. Fe, $\mathrm{R}^{2}=0.0794$ ); (As vs. $\mathrm{Mn}, \mathrm{R}^{2}=0.0121$ ) suggest that reductive dissolution of $\mathrm{MnOOH}$ and $\mathrm{FeOOH}$ where anaerobic bacteria represents a vital mechanism for arsenic releasing into the groundwater. The poor correlations among dissolved As, Fe and $\mathrm{SO}_{4}$ concentration (As vs. $\left.\mathrm{SO}_{4}, \mathrm{R}^{2}=0.0401\right)$; (Fe vs. $\mathrm{SO}_{4}, \mathrm{R}^{2}=0.0067$ ) in groundwater indicate that sulfide/pyrite is not the principal process of arsenic release into groundwater. Principal component and cluster analysis indicate that arsenic in groundwater source are of geogenic in origin.Based on $\mathrm{pH}$, TDS, $\mathrm{Ca}^{2+}$, $\mathrm{Mg}^{2+}, \mathrm{Na}^{+}, \mathrm{K}^{+}, \mathrm{Cl}^{-}, \mathrm{NO}_{3}{ }^{2-}, \mathrm{SO}_{4}{ }^{2-}$ (cations and anions) are within the standard limit which is suitable for domestic and drinking purposes and As, Fe, Mn (trace metal) values exceed the DOE and WHO standard are not suitable for human consumption. After calculate total hardness, SAR, SSP, KR, MH, TH, Na\%, PI and PS values, it can be concluded that the groundwater of the research area is good for irrigation purpose. The maximum (0.0105) and minimum (0.00047) cancer risk 
value got over the United States Environmental Protection Agency (USEPA) limit of $10^{-6}$ which strongly indicate that the people in the Bholadanga village were at extremely carcinogenic risk.

\section{References}

Ahmed KM, Bhattacharya P, Hasan MA, Akhter SH, Alam SMM, Bhuyian MAH, Imam MB, Khan AA, Sracek O (2004) Arsenic enrichment in groundwater of the alluvial aquifers in Bangladesh: an overview. ApplGeochem 19:181200

Ahsan MA, Satter F, Siddique MAB, Akbor MA, Ahmed S, Shajahan M, Khan R (2019) Chemical and physicochemical characterization of effluents from the tanning and textile industries in Bangladesh with multivariate statistical approach. Environ Monit Assess 191:575

Ayers RS, Westcot DW (1985) Water quality for agriculture. Irrigation and drainage paper No. 29. Food and agriculture organization of the United Nations, Rome 1-117

Chandu SN, Sibbarao NV, Prakash SR (1995) Suitability of groundwater for domestic and irrigational purposes in some parts of Jhansi District, U.P. Bhujal News 10(1):12-17

Chen CJ, Hsueh YM, Lai MS, Shyu MP, Chen SY, Wu MM, Kuo TL, Tai TY (1995) Increased prevalence of hypertension and long-term arsenic exposure. Hypertension 25:53-60

Chowdhury QI (2001) Bangladesh State of Arsenic 2001. Forum of Environmental Journalists of Bangladesh. Dhaka. Controls on pollution of groundwater by arsenic. In: Chappel WR, Abernathy CO, Calderon R (eds). Arsenic Exposure and Health Effects, Elsevier, Oxford, 53-78

Doneen LD (1964) Notes on water quality in agriculture. Published as a water science and engineering paper 4001, Department of Water Science and Engineering, University of California, Davis

Environment Protection Act (EPA) (1986) Act of the Parliament of India. In the wake of the Bhopal gas Tragedy or Bhopal Disaster 
Guha-Mazumder DN, Haque R, Ghose N, De BK, Santra A, Chakraborty D, Smith $\mathrm{AH}$ (2000) Arsenic in drinking water and the prevalence of respiratory effects in West Bengal, India. Int J Epidemiol. 29:1047-52

Harvey CF, Swartz CH, Badruzzaman ABM, Keon-Blute N, Yu W, Ashraf Ali M, Jay J, Beckie R, Niedan V, Brabander DJ, Oates PM, Ashfaque KN, Islam S, Hemond HF, Ahmed MF (2002) Arsenic mobility and groundwater extraction in Bangladesh. Science 298:1602-1606

Karanth KR (1987) Groundwater assessment development and management.Tata McGraw Hill Publishing Company Ltd., New Delhi, p 725

Kelly WP (1940) Permissible composition and concentration of irrigated waters. In: Proceedings of the A.S.C.F, 607

Khodapanah L, Sulaiman WNA, Khodapanah DN (2009) Groundwater quality assessment for different purposes in Eshtehard District, Tehran, Iran. Eur J Sci Res 36(4):543-553

Lin TH, Huang YL, Wang MY (1998) Arsenic species in drinking water, hair, fingernails, and urine of patients with blackfoot disease. J Toxicol Environ Health 53:85-93

Madison RJ, Brunett JO (1984) Overview of the occurrence of nitrate in groundwater of the united states, in National Water Summary 1984: U.S Geological Survey Water Paper 2275: 93-105.

Mandal BK, Suzuki KT (2002) Arsenic around the world: a review. Talanta 58:201-235

McArthur JM, Banjeree DM, Hudson-Edwards KA, Mishra R, Purohit R, Ravenscroft P, Cronin A, Howarth RJ, Chatterjee A, Talukder T, Lowry D, Houghton S, Chadha DK (2004) Natural organic matter in sedimentary basins and its relation to arsenic in anoxic ground water: the example of West Bengal and its worldwide implications. ApplGeochem. 19:1255-1293

Morales KH, Ryan L, Kuo TL, Wu MM, Chen CJ (2000) Risk of internal cancers from arsenic in drinking water. Environ Health Perspect 108:655-61

Ng JC, Wang J, Shraim A (2003) A global health problem caused by arsenic from natural sources. Chemosphere 52:1353-1359 
Paliwal KV (1967) Effect of gypsum application on the quality of irrigation water. Madras Agric J 59:646-647

Rabbani GH, Chowdhury AK, Shaha SK, Nasir M (2002) Mass arsenic poisoning of ground water in Bangladesh. Global Health Council Annual Conference Abstract in Proceedings, Washington DC May 28-June 1

Rahman M (2002) Arsenic and contamination of drinking-water in Bangladesh: a public-health perspective. J Health PopulNutr. 20:193-7

Ramesh K, Elango L (2012) Groundwater quality and its suitability for domestic and agricultural use in Tondiar River Basin, Tamil Nadu, India. Environ Monit Assess 184(6):3887-3899

Ravenscroft P, McArthur JM, Hoque BA (2001) Geochemical and palaeohydrological controls on pollution of groundwater by arsenic. In: Chappel WR, Abernathy CO, Calderon R (eds). Arsenic Exposure and Health Effects 4:53-78

Reza AHMS, Jean JS, Yang HJ, Lee MK, Woodall B, Liu CC, Lee JF, Luo SD (2010) Occurrence of arsenic in core sediments and groundwater in the Chapai-Nawabganj District, Northwestern Bangladesh. Water Res. 44:20212037

SchoellerHerri (1955) Geochemic des cauxSouterrnies; Revaue de L, Institute Francais du Petrole, 10: 230-244.

Smedley PL, Kinniburgh DG (2002) A review of the source, behaviour and distribution of arsenic in natural waters. ApplGeochem. 17:517-568

Srivastava AK, Hasan SK, Srivastava RC (2001) Arsenicism in India: dermal lesions and hair levels. Arch Environ Health 56:562

Todd DK (1980) Groundwater hydrology, 2nd edn. Wiley, New York, p 535

USEPA (1998) Arsenic, inorganic. United States Environmental Protection Agency, Integrated Risk Information System (IRIS), (CASRN 7440-38-2)

USEPA (2005) Guidelines for Carcinogen Risk Assessment; EPA/630/P-03/001F; Risk Assessment Forum: Washington, DC, USA 
Wilcox LV (1955) Classification and use of irrigation water. Washington, DC: US Department of Agriculture.

World Health Organization (WHO) (1997) Guideline for drinking water quality. HealthCriteria and Other Supporting Information, 2nd ed. vol. 2. World Health Organization,Geneva, 940-949

Zheng Y, Stute M, van Geen A, Gavrieli I, Dhar R, Simpson HJ, Schlosser P, Ahmed KM (2004) Redox control of arsenic mobilization in Bangladesh groundwater. ApplGeochem. 19:201-214 
Figures

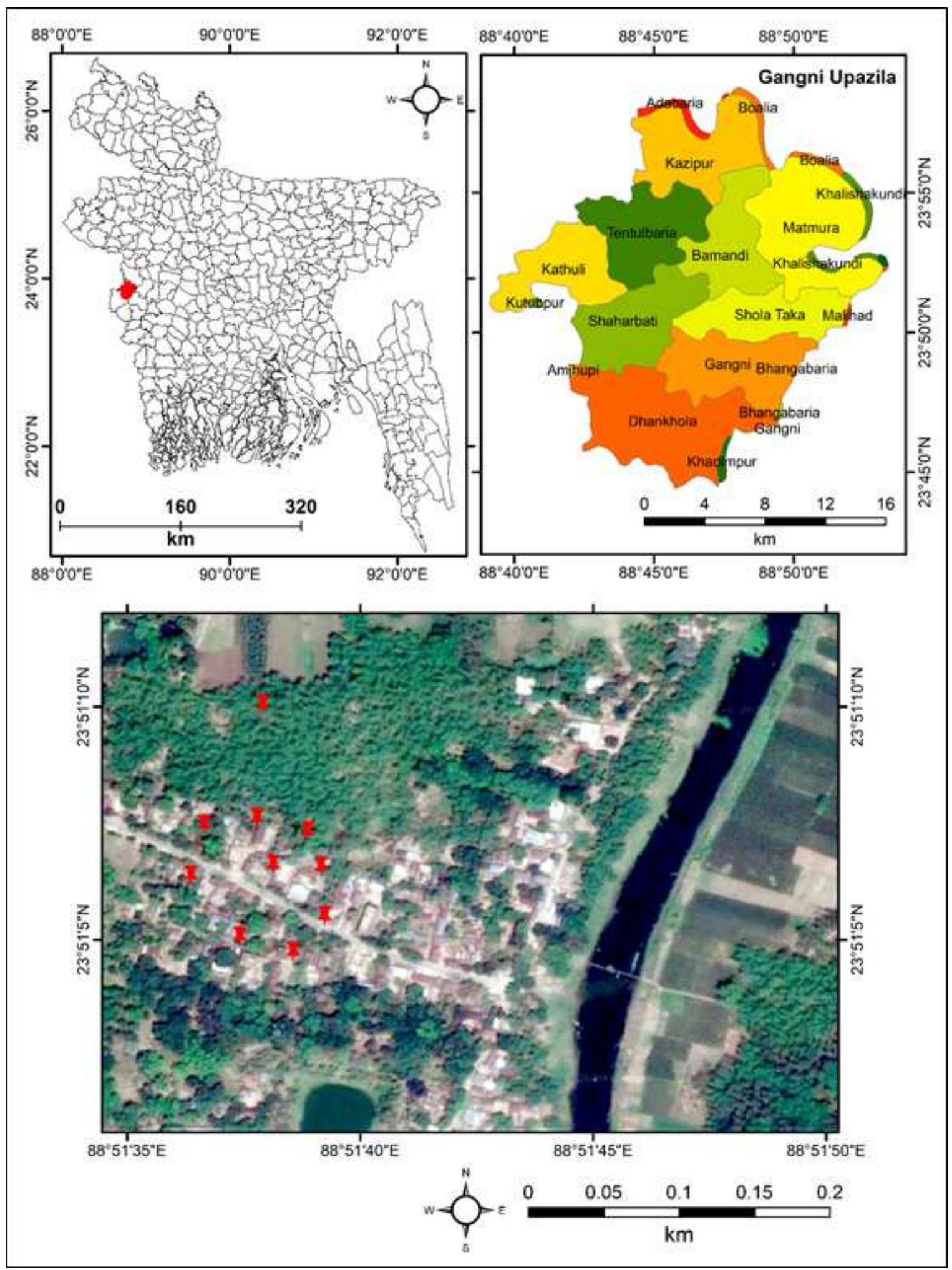

Figure 1

Location map of the study area 

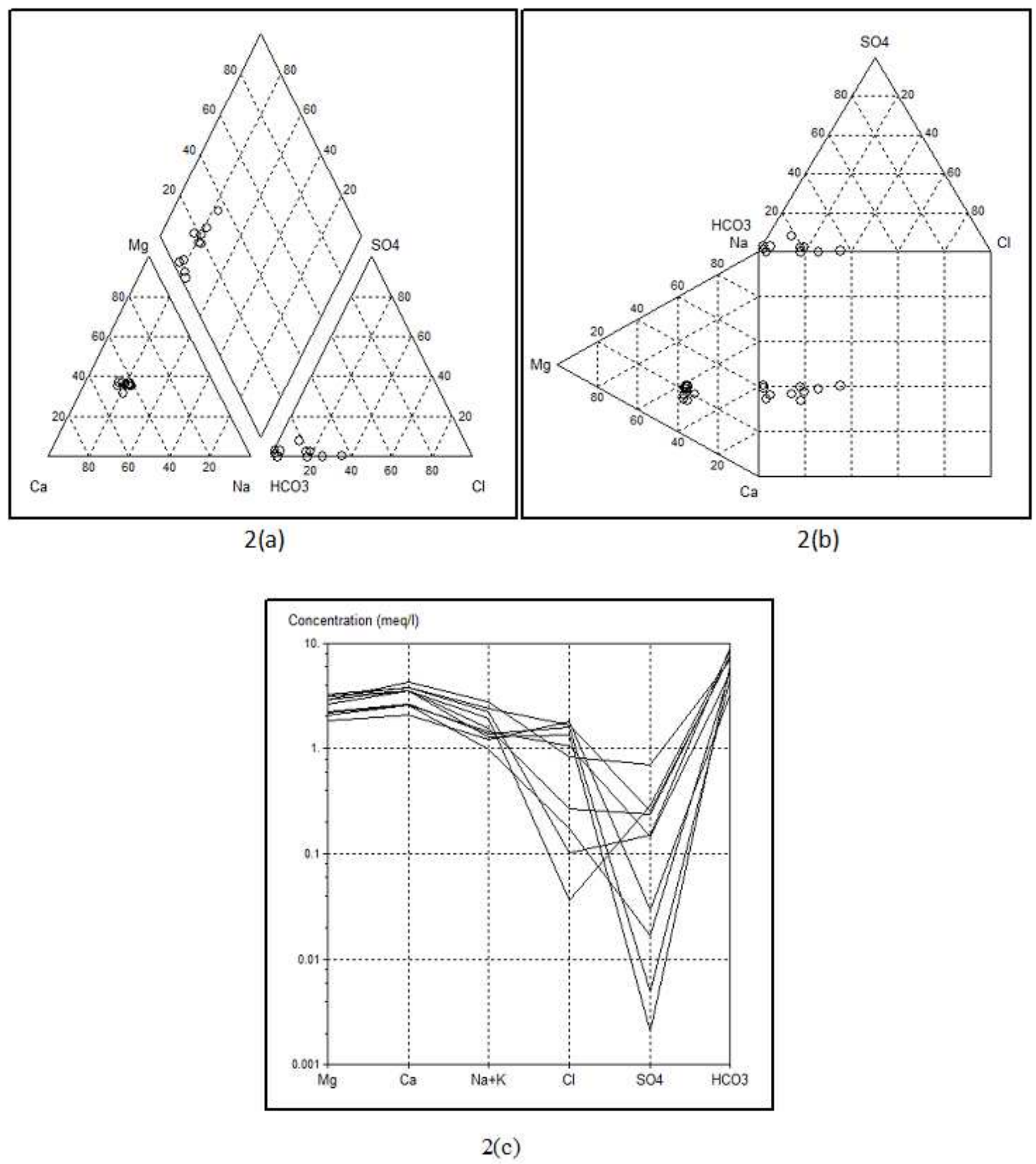

Figure 2

Piper diagram 2(a), Durov diagram 2(b) and Schoeller Semi Logarithmic diagram 2(c) of groundwater samples 


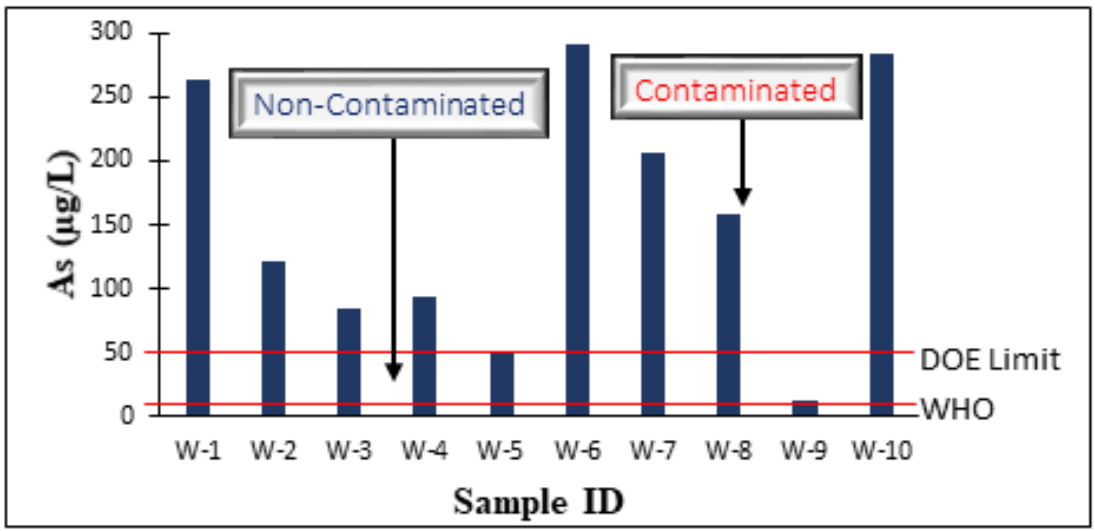

3 (a)

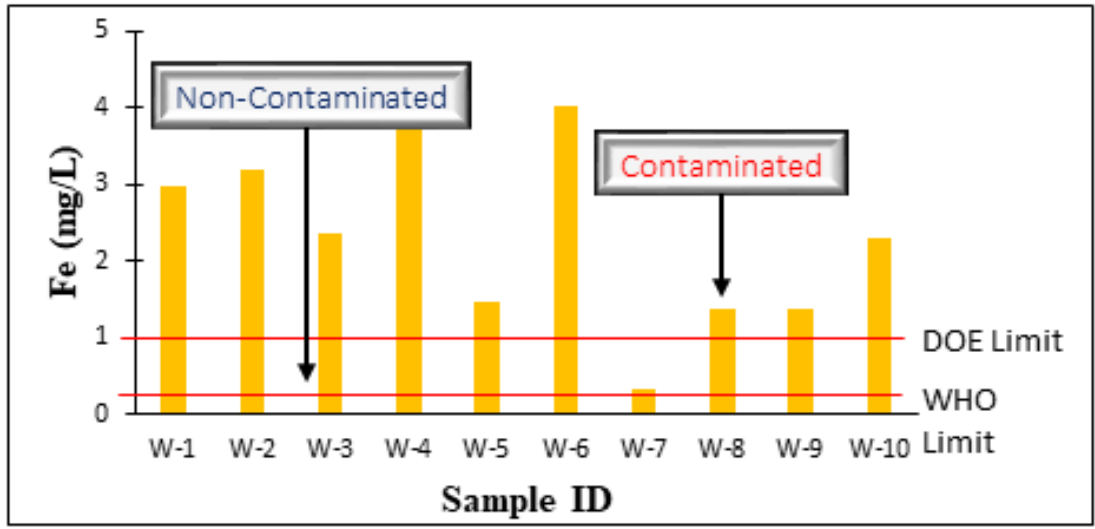

3 (b)

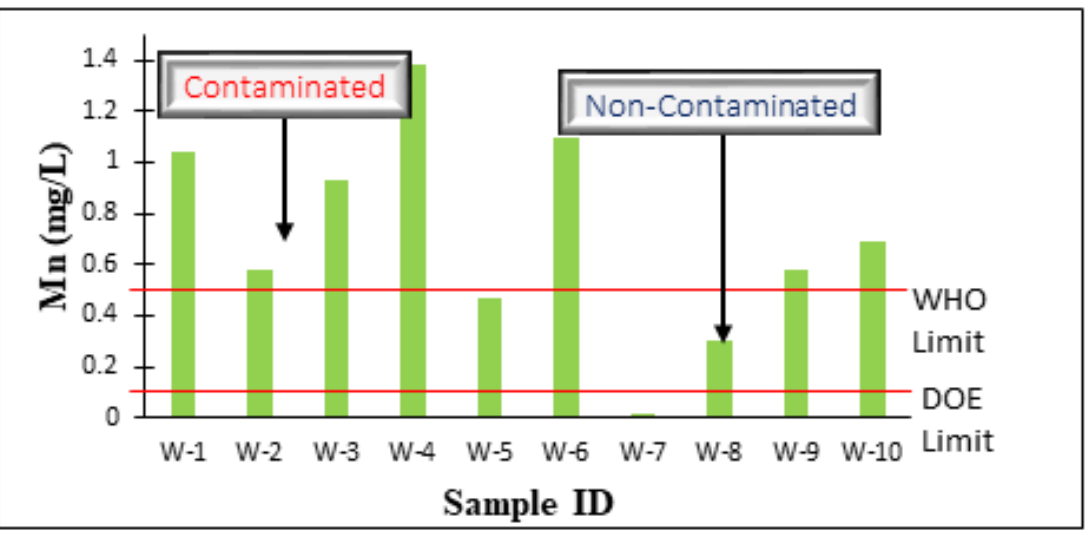

3 (c)

Figure 3

Contamination levels in the groundwater samples, 5 (a) As, 5 (b) Fe and 5 (c) Mn collected from the study area. 


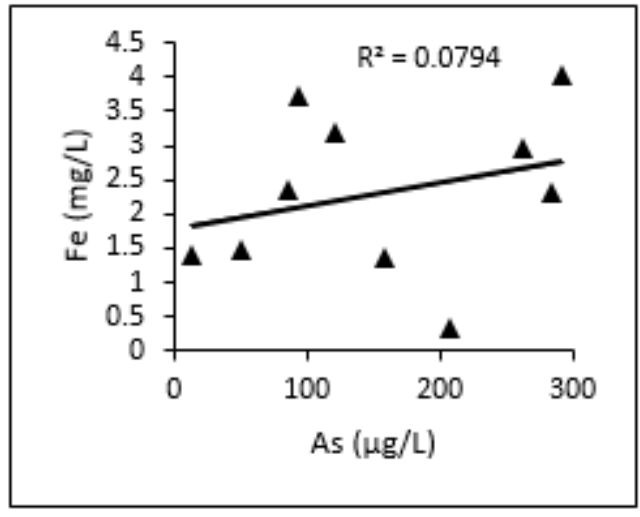

4(a) As vs. Fe



4(c) As vs. $\mathrm{SO}_{4}$

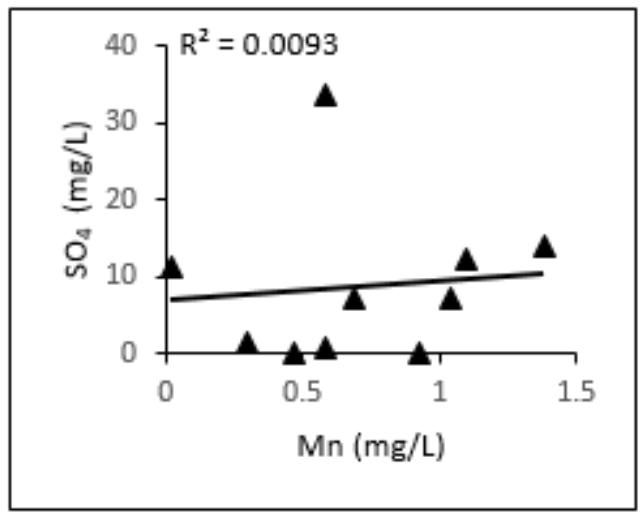

4(e) Mn vs. $\mathrm{SO}_{4}$

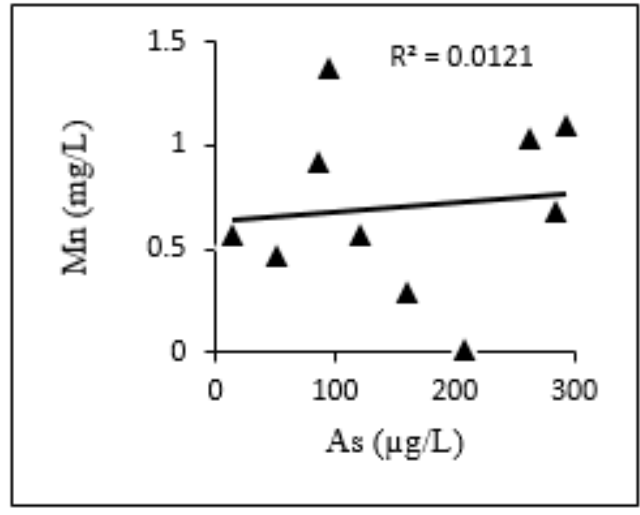

4(b) As vs. Mn

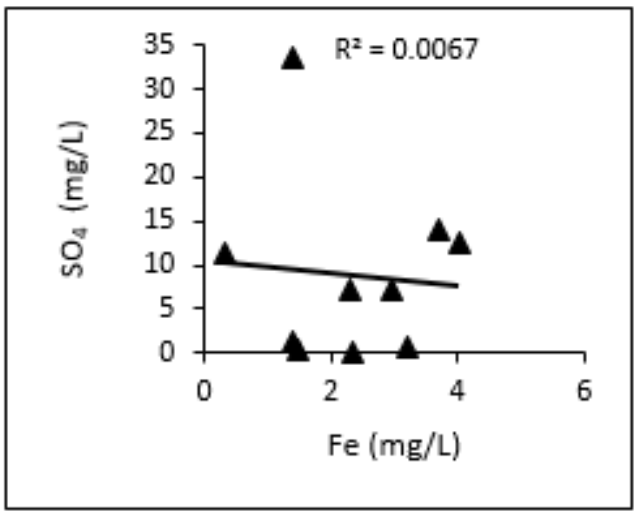

4(d) Fe vs. $\mathrm{SO}_{4}$

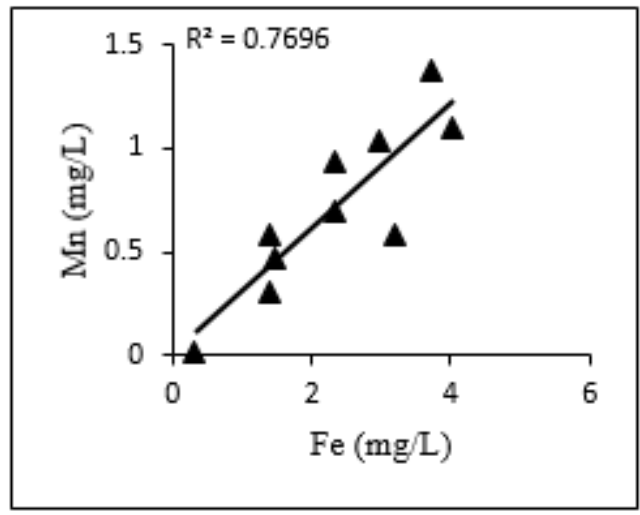

4(f) Fe vs. Mn

Figure 4

Correlations for 4(a) As vs. $\mathrm{Fe}, 4(\mathrm{~b})$ As vs. $\mathrm{Mn}, 4$ (c) As vs. $\mathrm{SO}_{4}, 4$ (d) Fe vs. $\mathrm{SO}_{4}, 4(\mathrm{e}) \mathrm{Mn}$ vs. $\mathrm{SO}_{4}$, and $4(\mathrm{f})$ Fe vs. Mn. 


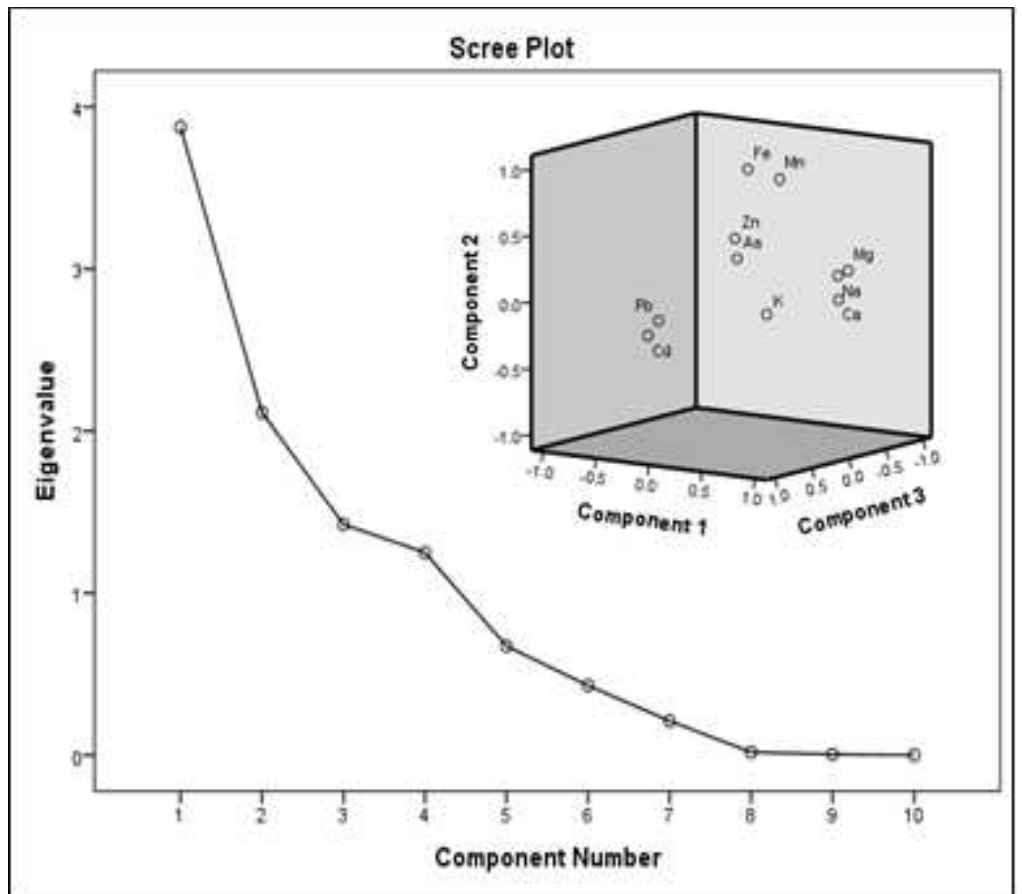

Figure 5

PCA analysis with component plot in rotated space and scree plot of metals.

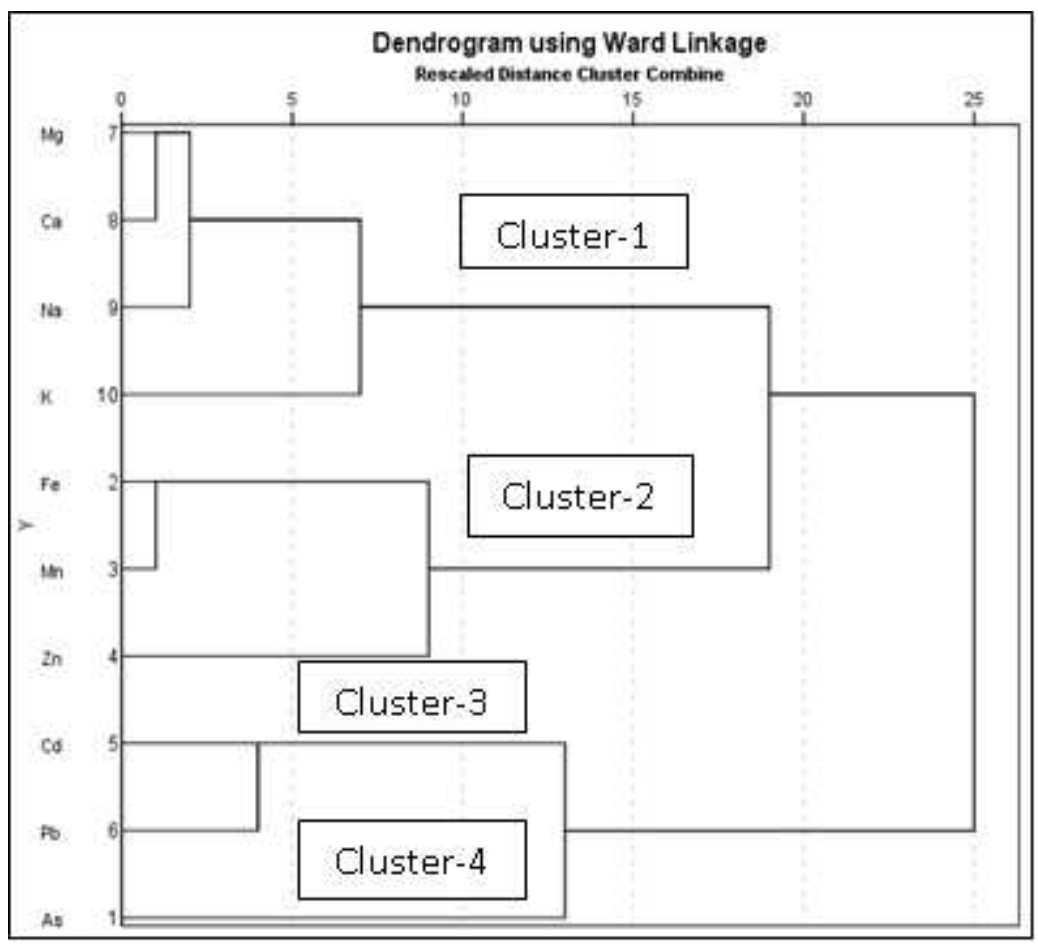

Figure 6

Cluster analysis of the groundwater samples 
